\title{
Osseous metaplasia in a gastric adenomatous polyp
}

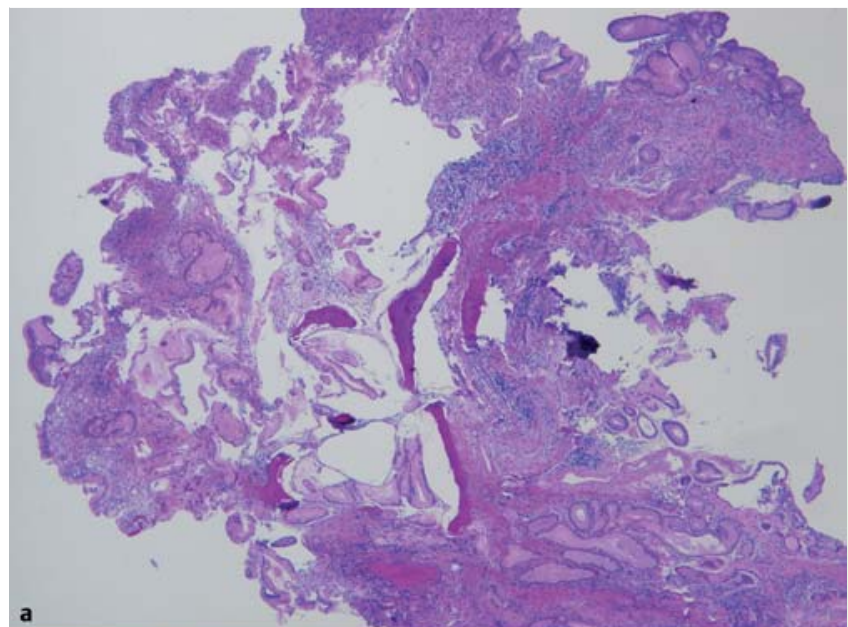

Fig. 1 a, b Areas of surface ulceration with granulation tissue and several foci of heterotopic bone formation in an adenomatous polyp of the stomach in a 71-year-old man with epigastric pain and dyspeptic syndrome.

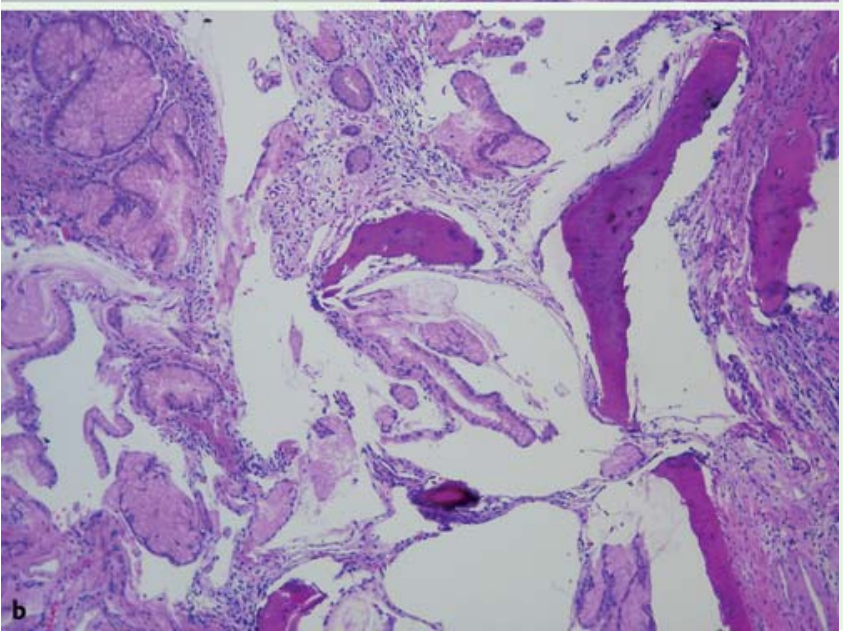

Endoscopy_UCTN_Code_CCL_1AB_2AD_3AF

Competing interests: None

\section{E. Zapata ${ }^{1}$, A. Castiella ${ }^{1}$, L. Zubiaurre ${ }^{1}$,} A. Agirre ${ }^{1}$, J. Rodriguez ${ }^{2}$

${ }^{1}$ Department of Gastroenterology, Mendaro Hospital, Mendarozabal Mendaro, Spain

2 Department of Pathology, Mendaro Hospital, Mendarozabal Mendaro, Spain

\section{References}

1 Olinici CD, Domşa I, Drăghici A et al. Heterotopic bone formation in gastric carcinoma. Case report and discussion of the literature. Rom J Gastroenterol 2002; 11 (4): 331-333

2 Wilsher MJ. Adenocarcinoma arising in a traditional serrated adenoma of the rectosigmoid colon with osseous metaplasia. Pathol Int 2011; 61 (4): 239-242

3 Narita T, Ohnuma H, Yokoyama S. PeutzJeghers syndrome with osseous metaplasia of the intestinal polyps. Pathol Int 1995; 45 (5): $388-392$

4 Oono Y, Fu KL, Nakamura $\mathrm{H}$ et al. Bone formation in a rectal inflammatory polyp. World J Gastrointest Endosc 2010; 2 (3): 104-106

5 Hayashi K, Ohtsuki Y, Sonobe $H$ et al. A case of malignant transformation of gastric hyperplastic polyp with metaplastic bone formation. Gan No Rinsho 1989; 35 (7): 851 854

6 Ohtsuki Y, Danbara Y, Takeda I et al. Metaplastic bone formation in a hyperplastic polyp of the stomach: a case report. Acta Med Okayama 1987; 41 (1): 43-46 gastrointestinal tract. In the majority of reported cases, it was associated with malignant lesions [1,2], Peutz-Jeghers syndrome [3], and more rarely with inflammatory colonic polyps [4]. On reviewing the literature, we found only two cases of metaplastic bone accompanying hyperplastic gastric mucosa [5,6], and no case report of osseous metaplasia in gastric adenoma of the stomach.

We report a case of a 71-year-old man who presented to our clinic with a history of epigastric pain and dyspeptic syndrome for the past 2 months. He had ulcerative colitis and had been on treatment with salicylates for a long time; he also had chronic hepatitis $\mathrm{C}$. Because of these symptoms, we conducted upper gastrointestinal endoscopy, which revealed a pedunculated polyp in the antrum. The polyp was excised, retrieved, and sent for histological examination. Histologically, the specimen demonstrated an adenomatous polyp with areas of surface ulceration, granulation tissue, and several foci of heterotopic bone formation ( $\mathbf{F i g} \mathbf{1}$ ). The pathogenesis of osseous metaplasia in the gastrointestinal tract remains poorly understood. It may be that either local or unknown osteogenic factors secreted by the lesion stimulate the osteoblasts, or that the osteogenic stimulation may be a result of inflammation. The finding of bone metaplasia seems to have no clinical significance.

In conclusion, osseous metaplasia in gastric adenoma is an extremely rare phenomenon in which the mechanism responsible for the osseous histogenesis is as yet not known.
Bibliography

Dol http://dx.doi.org/

10.1055/s-0031-1291608

Endoscopy 2012; 44: E81

(c) Georg Thieme Verlag KG

Stuttgart · New York

ISSN 0013-726X

\section{Corresponding author}

\section{E. Zapata}

Mendaro Hospital - Gastroenterology Department Mendarozabal Mendaro 20850

Spain

Fax: +003-494-3032860

evingerzap@yahoo.es 